\title{
Fictionalizing the Robot and Artificial Intelligence
}

\author{
Nathalie Weidenfeld
}

\begin{abstract}
This text explores the contemporary fascination with robots and digitality and points out how this distorts our view on what digitization can do for us. It pleads for a realist and non-fictionalized view on robots and artificial intelligence.
\end{abstract}

Nothing in our contemporary popular culture, so it seems, has been more fascinating than the fantasy of robots and the idea of an upcoming total digitization of our society. Hollywood is full of blockbuster films filled with evil, sometimes beautiful robots and dreams of eternal or at least alternative lives made possible through digital means.

Films however are not only expressions of deep-seated fears and hopes, they also create a cultural imaginary that feeds into these fears and hopes, thereby creating a loop that is best described as a more or less closed circle. Now, artistic creations are and should of course be free to do many things; they may create unrealistic settings and invent dramatic premises which make us wonder. Problems only arise when readers or viewers forget to read these films correctly, that is, metaphorically. Take a film about a society in which robots are used as personal slaves for household chores, where the protagonist must learn to overcome his prejudice toward them robots. Does this film incite us to think about our relationships to future robots? No! Because this film is not about robots but a metaphorical tale about humans dealing with humans in which robots represent underprivileged humans.

Digitalization and artificial intelligence pose many problems for society and culture. It is therefore of utmost importance to see them for what they are in order to judge their potentials and their dangers realistically. An inadequate "import" of fiction into reality is useless and unproductive.

In order to see more clearly what exactly has been imported from fiction into reality, let's take a closer look at narratives focused on AI. When we look at films particularly the ones in the last 20 years - dealing with the topos of the robot, we can

\footnotetext{
N. Weidenfeld $(\bowtie)$

Munich, Germany

e-mail: weidenfeld@nida-ruemelin.de

(C) The Author(s) 2022 
discern two types: the good, innocent, and sometimes even spiritual robot and the bad, demonical, and evil robot. These two stereotypes are an expression of a paradigm that can be called "primitivist." The primitivistic paradigm is a "cultural reflex" of Western society in need to construct an "Other" that can then be used as a mirror (Torgovnick 1990): a mirror onto which one can project one's own beloved or hated properties. American Indians have long served as Other within the primitivist order - not only in the time of the European Enlightenment but also in the US American culture: During centuries, Indians were either portrayed as bloodthirsty demonic savages or as innocent and spiritually superior people. The American Indian as a topos remains an obsession for US American novels and films, starting with narratives in the seventeenth century dealing with Puritan settlers abducted by bloodthirsty Indians, all through the nineteenth century where narratives of the noble Indian become popular up to the New Age image of the spiritually and morally idealized Indian.

Societies not only create an imaginary Other from already existing real persons but also create them from time to time. The best example for this is the Alien, who became a primitivist topos in the 1980s. The Aliens were portrayed along the same lines as the Indians beforehand: They were either evil and bloodthirsty or good and spiritually highly developed (Weidenfeld 2007a, b). Today, the robots have taken over the role of the Aliens. This primitivist mode of conceptionalizing robots has a deep influence on present society. If Elon Musk or even Stephen Hawking warns us and speaks of lurking dangers and threats which robots pose for humanity - they serve the same old primitivist cliché of the evil Other. What they are doing is not an adequate or realistic description, but rather an inscription into an already existing narrative which is at the same time re-introduced into the world.

When one looks into narratives and images of digitization, one encounters similar mechanisms. Digitization is either seen as a mode of bringing about a digital paradise or digital hell. The idea of a digital heaven is often invoked by images of clarity, a blue sky, and an overwhelming universe of all-connectedness. Digital heaven is a puritan heaven: It is based on the idea of transparency, clarity, and purity. In a digital universe, things are either " 0 " or " 1 "; there is no ambiguity. Also, the idea of a "natural" teleological development is often suggested in the visual imagery which tells us that man has evolved from ape, to homo sapiens, to homo digitalis - often represented as man holding a portable phone in hand. Digital future becomes a millenaristic prophecy filled with utopian hopes and desires such as the desire for salvation and eternal life.

In the past centuries, technological developments have often been accompanied by unrealistic utopian visions. When Henry Ford pioneered in the mass production of the automobile, he was convinced that this new technology would bring about peace and prosperity for all. "We are about to enter a new era because when we have everything, freedom and paradise on earth will come. Our new way of thinking and acting will bring us a new world, a new heaven and a new earth, as prophets have longed for since age old times" (Ford 1919). Roughly a hundred years after the automobile, it is digitization that will supposedly bring salvation. CEOs in Silicon Valley upload their presentations with images which suggest this. 
Digital hell is represented mostly in three possible modes: It is either a digitally economized hell like the world of Bladerunner or Minority Report, where digital means are used for advertising; or a fascist world, where one ruler has used digital means in order to erect not only his reign but also uniformity and absolute synchronicity; or at least a nightmarish digital world such as in the film Matrix, where humans have lost all autonomy and self-determination.

Utopian and dystopian fantasies have moved out of the realm of films and novels into our daily expectations. These religiously motivated expectations take much energy away from that, what is important: discussions on and clarifications of concrete ethical problems that digitization poses.

Lastly, there is a psychological aspect which Rudolf Dux named the "Frankenstein complex" (Dux 1999): the dream of creating a lifelike being that can feel and think like us. This animistic dream, which Freud described so well in Totem and Taboo (Freud 1974), is part of a regressive fantasy, similar to a child's wish to fill a doll with life in order to feel powerful and/or not so lonely anymore.

From the student Nathanael in E.T.A. Hofmann's tale "Der Sandmann" up to the visions of femme fatale robots such as AVA in Ex Machina, the dream remains the same: a regressive dream of humanlike companionship which is never quite humanlike but humanlike enough to make us dream of whatever we desire: total love, total communion, or total friendship.

"Get a relationship" is the slogan of sex robot critic Prof. Kathleen Richardson who argues against the development of more and more sophisticated lifelike female robots who take humans' attention away from what is really important, namely, relationships with each other (Richardson 2022).

Digital humanism puts human relationships first and aims at thinking and using digital technologies instrumentally (Nida-Rümelin and Weidenfeld 2018). Digital tools were neither made by demons nor angels, but by humans for humans. It is time to keep this in mind and stop introducing fictional imaginary and topoi in our everyday language and discourse. We need a clear and realistic judgement, unclouded by dreams, projections, and regressive fantasies.

\section{References}

Dux, R. (eds.) (1999). Der Frankenstein-Komplex. Frankfurt: Suhrkamp.

Ford, H. (1919) Philosophie der Arbeit. Dresden, p. 47.

Freud, S. (1974). Totem und Tabu. Frankfurt: Fischer Verlag.

Nida-Rümelin, J. and Weidenfeld, N. (2018) Digitaler Humanismus: Eine Ethik für das Zeitalter der Künstlichen Intelligenz. Munich: Piper.

Richardson, K. (2022) Sex Robots: The End of Love. Cambridge: Polity Press.

Torgovnick, M. (1990). Gone Primitive. University of Chicago Press, 1990.

Weidenfeld, N.. (2007a) Entführt von Außerirdischen: Abduction Narrative als moderne.

Weidenfeld, N. (2007b) Entführt von Außerirdischen: Abduction Narrative als moderne n: Abduction Narrative als moderne Erscheinungsform puritanischer Kultur. Saarbrücken: Südwestdeutscher Verlag. 
Open Access This chapter is licensed under the terms of the Creative Commons Attribution 4.0 International License (http://creativecommons.org/licenses/by/4.0/), which permits use, sharing, adaptation, distribution and reproduction in any medium or format, as long as you give appropriate credit to the original author(s) and the source, provide a link to the Creative Commons license and indicate if changes were made.

The images or other third party material in this chapter are included in the chapter's Creative Commons license, unless indicated otherwise in a credit line to the material. If material is not included in the chapter's Creative Commons license and your intended use is not permitted by statutory regulation or exceeds the permitted use, you will need to obtain permission directly from the copyright holder. 